\title{
Hubungan Indeks Massa Tubuh dengan Laju Aliran Saliva pada Mahasiswa Program Studi Pendidikan Dokter Gigi Universitas Sam Ratulangi
}

\author{
${ }^{1}$ Vena Fernanda \\ ${ }^{2}$ Damajanty H. C. Pangemanan \\ 1'Johanna A. Khoman \\ ${ }^{1}$ Program Studi Pendidikan Dokter Gigi Fakultas Kedokteran \\ ${ }^{2}$ Bagian Fisiologi Fakultas Kedokteran \\ Universitas Sam Ratulangi Manado \\ Email: fernandavena18@gmail.com
}

\begin{abstract}
Body Mass Index (BMI) can be used as an indicator to obtain the nutritional status of an individual. Poor nutritional status can influence salivary flow rate resulting in several diseases in the oral cavity such as xerostomia, caries, etc. This study was aimed to obtain the relationship between BMI and salivary flow rate in college students of the Dentistry Program of Sam Ratulangi University. This was an analytical descriptive study with a cross sectional design conducted in 54 college students of the Dentistry Program of Sam Ratulangi University. BMI was calculated in $\mathrm{kg} / \mathrm{m}^{2}$ meanwhile the salivary flow rate was determined with unstimulated saliva collection method in $\mathrm{ml} /$ minute. Data were analyzed by using Pearson correlation test. The results showed that there were 54 subjects consisted of 12 males and 42 females with an age range of 18-22 years old. Most of the subjects had normal BMI (9.26\% in males and $42,59 \%$ in females). Normal BMI was most common in subjects aged 21 years $(16,67 \%)$. The lowest salivary flow rate $(0.10 \mathrm{ml} /$ minute $)$ was $1.85 \%$ and the highest salivary flow rate $(0.33 \mathrm{ml} /$ minute $)$ was $16.67 \%$. The Pearson correlation test showed $P=$ $0.000(<0.05)$ and $r=-0.756$. Conclusion: In this study, there was a significant negative relationship between BMI and salivary flow rate in college students of the Dentistry Program of Sam Ratulangi University.
\end{abstract}

Keywords: BMI, salivary flow rate

\begin{abstract}
Abstrak: Indeks massa tubuh (IMT) dapat digunakan sebagai indikator untuk mengetahui status gizi seseorang. Status gizi buruk dapat memengaruhi laju aliran saliva sehingga dapat menyebabkan berbagai macam penyakit di dalam rongga mulut antara lain xerostomia dan karies. Penelitian ini bertujuan untuk mengetahui hubungan IMT dengan laju aliran saliva pada mahasiswa PSPDG Unsrat. Jenis penelitian ini ialah deskriptif analitik dengan desain potong lintang yang dilakukan pada 54 mahasiswa PSPDG Unsrat. IMT ditentukan dalam satuan $\mathrm{kg} / \mathrm{m}^{2}$ dan laju aliran saliva ditentukan dengan metode pengumpulan unstimulated saliva dengan satuan $\mathrm{ml} /$ menit. Data dianalisis menggunakan uji korelasi sederhana Pearson untuk mengetahui hubungan IMT dengan laju aliran saliva. Hasil penelitian mendapatkan 54 subyek penelitian terdiri dari 12 laki-laki dan 42 perempuan dengan usia 18-22 tahun. Nilai IMT pada laki-laki dan perempuan paling banyak terdapat pada kategori normal $(9,26 \%$ dan $42,59 \%)$. IMT normal berdasarkan usia paling banyak terdapat pada usia 21 tahun sebanyak 9 subyek $(16,67 \%)$. Laju aliran saliva terendah $(0,10 \mathrm{ml} /$ menit $)$ sebanyak $1,85 \%$ dan laju aliran saliva tertinggi $(0,33 \mathrm{ml} / \mathrm{menit})$ sebanyak $16,67 \%$. Uji korelasi sederhana Pearson menunjukkan nilai $P=0,000(<0,05)$ dan $r=-0,756$. Simpulan: Terdapat hubungan negatif yang bermakna antara IMT dengan laju aliran saliva pada mahasiswa PSPDG Unsrat.
\end{abstract}

Kata kunci: IMT, laju aliran saliva 
Derajat kesehatan masyarakat dinilai dengan menggunakan beberapa indikator salah satunya yaitu status gizi. Status gizi pada kelompok dewasa berusia 18 tahun ke atas di Indonesia didominasi oleh masalah obesitas, yang menandakan bahwa tingkat kategori indeks massa tubuh (IMT) semakin tinggi. Nilai IMT dapat digunakan sebagai indikator untuk mengetahui prevalensi status gizi orang dewasa dimulai pada usia 18 tahun ke atas. Laporan Riskesdas 2010, provinsi dengan prevalensi kelebihan berat badan penduduk 18 tahun ke atas tertinggi yaitu Sulawesi Utara dengan persentase sebesar $37,1 \%{ }^{1}$

Status gizi dapat memengaruhi laju aliran saliva, ${ }^{2}$ yang merupakan parameter aliran saliva baik dengan adanya pemberian atau tanpa pemberian stimulus. ${ }^{3}$ Saliva merupakan cairan eksokrin yang dikeluarkan ke dalam rongga mulut melalui kelenjar saliva. Secara umum, saliva berperan dalam proses pencernaan makanan, pengaturan keseimbangan air, sebagai cleansing solution, ion reservoir untuk kalsium dan fosfat yang penting untuk remineralisasi penyebab lesi karies, menjaga integritas gigi, aktivitas antibakterial, buffer, dan berperan penting bagi kesehatan rongga mulut. ${ }^{3,4}$ Sifat-sifat saliva terdiri dari laju aliran saliva, pH saliva, dan kapasitas buffer saliva. ${ }^{5}$

Status gizi yang buruk dapat memengaruhi sekresi dan komposisi saliva sehingga menyebabkan laju aliran saliva berkurang yang dapat memengaruhi kualitas hidup individu. ${ }^{2}$ Individu dengan laju aliran saliva rendah berpeluang mengalami xerostomia, mucosal inflammation, burning mouth, gangguan pengecapan, demineralisasi gigi, kesulitan pengunyahan, gangguan bicara, retensi gigi tiruan yang buruk, candidiasis, penyakit periodontal, dan meningkatkan jumlah bakteri penyebab karies. $^{6-8}$

Penelitian oleh Yulyius et al. ${ }^{9}$ terhadap mahasiswa Program Studi Pendidikan Dokter angkatan 2013 Fakultas Kedokteran Universitas Sam Ratulangi melaporkan bahwa mahasiswa dengan status gizi normal sebesar $79 \%$, gizi lebih dan obesitas sebesar $16 \%$, dan hanya $5 \%$ yang memiliki gizi kurang. Penelitian tentang hubungan Body Mass Index dengan laju aliran saliva yang dilakukan oleh Fajrin et al. ${ }^{2}$ di Padang terhadap mahasiswa Fakultas Kedokteran Gigi Universitas Andalas menyatakan bahwa Body Mass Index (BMI) dengan laju aliran saliva memiliki hubungan yaitu semakin besar BMI maka laju aliran saliva semakin lambat. $^{2}$

Penelitian ini bertujuan untuk mengetahui hubungan IMT dengan laju aliran saliva mengingat obesitas telah menjadi masalah global

\section{METODE PENELITIAN}

Jenis penelitian ini ialah deskriptif analitik dengan desain potong lintang. Penelitian ini dilaksanakan di Program Studi Pendidikan Dokter Gigi Universitas Sam Ratulangi Manado. Sampel diperoleh dengan metode total sampling.

Subyek penelitian ini yaitu mahasiswa angkatan 2014-2017 di PSPDG Unsrat dan diperoleh sebanyak 54 subyek kemudian dilakukan pengukuran IMT dan pemeriksaan laju aliran saliva. Pengukuran IMT diperoleh melalui pengukuran berat badan dan tinggi badan, sedangkan laju aliran saliva diperoleh melalui pengumpulan saliva dengan metode unstimulated saliva yakni dengan cara posisi subyek berdiri tegak lurus terhadap lantai dan diinstruksikan untuk mengumpulkan saliva di dalam rongga mulut selama 3 menit dengan cara menunduk. Saliva yang telah terkumpul kemudian diludahkan ke dalam tabung centrifuge yang dilengkapi dengan funnel dan diukur.

Data yang diperoleh diolah dengan menggunakan program SPSS dan disajikan dalam bentuk tabel distribusi frekuensi.

\section{HASIL PENELITIAN}

Berdasarkan jenis kelamin dari 54 subyek terdapat 12 subyek $(22,22 \%)$ berjenis kelamin laki-laki dan 42 subyek $(77,78 \%)$ berjenis kelamin perempuan. Berdasarkan usia dari seluruh subyek penelitian terdapat 8 subyek $(14,81 \%)$ berusia 18 tahun, 16 subyek $(29,63 \%)$ 
berusia 19 tahun, 15 subyek $(27,78 \%)$ berusia 20 tahun, 13 subyek $(24,07 \%)$ berusia 21 tahun, dan 2 subyek $(3,70 \%)$ berusia 22 tahun.

Distribusi hasil penilaian IMT dan hasil pemeriksaan laju aliran saliva dapat dilihat pada Tabel 1 dan 2. Data hasil pemeriksaan IMT dan laju aliran saliva diuji menggunakan uji normalitas Kolmogorov-Smirnov untuk melihat distribusi normal dari masing-masing variabel kemudian hubungan antara variabel diuji dengan uji korelasi sederhana Pearson (Tabel 3).

Pada uji normalitas KolmogorovSmirnov didapatkan nilai $P=0,2(P>0,05)$ yang menunjukkan bahwa data terdistribusi normal. Hubungan IMT dengan laju aliran saliva diuji dengan korelasi sederhana yang menunjukkan terdapat hubungan bermakna antara kedua variabel yakni memiliki nilai signifikansi (Sig.) $0,000 \quad(P<0,05)$ dan memiliki nilai Pearson correlation sebesar $-0,756$ yang menunjukkan hubungan korelasi negatif yang kuat yang berarti bahwa semakin besar IMT maka laju aliran saliva akan semakin rendah.
Tabel 1. Distribusi hasil penilaian IMT

\begin{tabular}{ccc}
\hline $\begin{array}{c}\text { Kategori IMT } \\
\left(\mathbf{k g} / \mathbf{m}^{\mathbf{2}}\right)\end{array}$ & $\begin{array}{c}\text { Jumlah } \\
(\mathbf{n})\end{array}$ & $\begin{array}{c}\text { Persentase } \\
(\mathbf{\%})\end{array}$ \\
\hline Kurus & 15 & 27,78 \\
Normal & 28 & 51,85 \\
BB lebih & 6 & 11,11 \\
Obesitas & 5 & 9,26 \\
Total & 54 & 100
\end{tabular}

Tabel 2. Distribusi hasil pemeriksaan laju aliran saliva

\begin{tabular}{ccc}
\hline $\begin{array}{c}\text { Laju aliran saliva } \\
(\mathbf{m l} / \text { menit })\end{array}$ & $\begin{array}{c}\text { Jumlah } \\
(\mathbf{n})\end{array}$ & $\begin{array}{c}\text { Persentase } \\
(\boldsymbol{\%})\end{array}$ \\
\hline 0,10 & 1 & 1,85 \\
0,13 & 2 & 3,70 \\
0,16 & 2 & 3,70 \\
0,20 & 3 & 5,56 \\
0,23 & 3 & 5,56 \\
0,25 & 13 & 24,07 \\
0,26 & 5 & 9,26 \\
0,28 & 6 & 11,11 \\
0,30 & 10 & 18,52 \\
0,33 & 9 & 16,67 \\
Total & 54 & 100 \\
\hline
\end{tabular}

Tabel 3. Hubungan indeks massa tubuh dengan laju aliran saliva

\begin{tabular}{|c|c|c|c|c|c|c|c|}
\hline \multirow{2}{*}{ IMT $\left(\mathrm{kg} / \mathrm{m}^{2}\right)$} & \multicolumn{2}{|c|}{ Normal } & \multicolumn{2}{|c|}{ Rendah } & \multicolumn{2}{|c|}{ Total } & \multirow[b]{2}{*}{$p$} \\
\hline & $\mathrm{n}$ & $\%$ & $\mathrm{n}$ & $\%$ & $\mathrm{n}$ & $\%$ & \\
\hline Kurus & 15 & 27,78 & 0 & 0,00 & 15 & 27,78 & \\
\hline Normal & 28 & 51,85 & 0 & 0,00 & 28 & 51,85 & \\
\hline BB lebih & 0 & 0,00 & 6 & 11,11 & 6 & 11,11 & 0,000 \\
\hline Obesitas & 0 & 0,00 & 5 & 9,26 & 5 & 9,26 & \\
\hline Total & 43 & 79,63 & 11 & 20,37 & 54 & 100 & \\
\hline
\end{tabular}

\section{BAHASAN}

Laju aliran saliva dipengaruhi oleh banyak faktor seperti usia, kehilangan dan restorasi gigi, skor DMF-T, dan status gizi. Status gizi yang tidak normal dapat memengaruhi sekresi dan komposisi saliva sehingga menyebabkan laju aliran saliva berkurang. ${ }^{2,10,11}$ Status gizi dapat dinyatakan dalam suatu indikator yaitu indeks massa tubuh (IMT). ${ }^{12}$ Status gizi yang tidak normal contohnya obesitas yang dikarakteristikkan sebagai salah satu epidemi glo- bal dari WHO dan dideskripsikan sebagai penyakit multifaktorial yang berhubungan dengan metabolik, endokrinologikal, dan tingkah laku yang menyebabkan tingginya lemak pada tubuh. ${ }^{13}$ Obesitas dapat menyebabkan berbagai masalah kesehatan, seperti resistensi insulin, hipertensi, dislipidemia, asma, serangan jantung, stroke, dan arterosklerosis. ${ }^{14}$

Individu yang mengalami obesitas memiliki komposisi bakteri saliva yang berbeda, perubahan dari konsentrasi akti- 
vitas sialic acid, fosfor, protein dan imunoglobulin, serta peroksidase yang menyebabkan laju aliran saliva menurun yang memicu terjadinya karies dan penyakit periodontal. ${ }^{14,15}$ Individu dengan laju aliran saliva rendah akan mengalami xerostomia, mucosal inflammation, burning mouth, gangguan pengecapan, demineralisasi gigi, kesulitan pengunyahan, gangguan bicara, retensi gigi tiruan yang buruk, candidiasis, penyakit periodontal dan meningkatkan jumlah bakteri penyebab karies. ${ }^{6-8}$

Hasil uji statistik pada penelitian ini menunjukkan bahwa terdapat hubungan bermakna antara IMT dengan laju aliran saliva $(P=0,000)$. Hubungan antara IMT berkorelasi kuat dengan arah negatif yang artinya semakin besar IMT maka akan semakin rendah laju aliran saliva. Laju aliran saliva bernilai normal pada subyek dengan IMT kategori kurus dan normal, dan menurun pada kategori berat badan lebih dan obesitas. Subyek dengan kategori obesitas memiliki nilai laju aliran saliva yang paling rendah dibandingkan dengan tiga kategori IMT lainnya.

Penelitian ini sejalan dengan penelitian yang dilakukan oleh Yas ${ }^{16}$ tentang hubungan laju aliran saliva dan karies pada individu BB lebih dan obesitas pada sampel dewasa berusia 30-40 tahun sebanyak 35 orang. Yas menyatakan bahwa laju aliran saliva pada individu berat badan lebih dan obesitas lebih rendah dibandingkan dengan individu nonobes. Modeer et al. ${ }^{10}$ menyatakan semakin bertambahnya IMT maka laju aliran saliva akan meningkat, tetapi pada sampel orang dewasa yang berusia 50 tahun dengan nilai IMT lebih dari 25 ditemukan bahwa laju aliran saliva semakin berkurang. Selain itu, penelitian yang dilakukan oleh Sawair et al. ${ }^{11}$ tentang unstimulated salivary flow rate pada lansia di Jordan melaporkan bahwa semakin tinggi kategori IMT maka laju aliran saliva semakin rendah. Hal ini sesuai dengan hasil penelitian ini yang juga menggunakan metode pengukuran unstimulated salivary flow rate.

Penelitian yang serupa dilakukan oleh Fajrin et al. ${ }^{2}$ terhadap mahasiswa Fakultas
Kedokteran Gigi Universitas Andalas yang menyimpulkan bahwa terdapat hubungan bermakna antara Body Mass Index dengan laju aliran saliva. Kelompok obesity memiliki laju aliran saliva yang lebih rendah dibandingkan dengan individu non obese (underweight, normal weight, dan overweight), sedangkan pada individu underweight tidak ditemukan penurunan laju aliran saliva. Penelitian Fajrin et al. ${ }^{2}$ sejalan dengan hasil penelitian ini yang menggunakan mahasiswa angkatan 2014 2017 Program Studi Pendidikan Dokter Gigi Universitas Sam Ratulangi yaitu individu dengan IMT kategori obesitas memiliki laju aliran saliva yang lebih rendah dari kategori lainnya dan pada individu dengan IMT kategori kurus tidak ditemukan adanya penurunan laju aliran saliva.

\section{SIMPULAN}

Berdasarkan hasil penelitian ini dapat disimpulkan bahwa terdapat hubungan negatif yang bermakna antara IMT dengan laju aliran saliva yakni semakin besar IMT maka laju aliran saliva semakin rendah.

\section{SARAN}

Individu yang memiliki IMT dengan kategori obesitas disarankan untuk menurunkan berat badan dan lebih memperhatikan kebersihan mulut karena dapat mengalami penurunan laju aliran saliva yang berisiko menyebabkan berbagai macam penyakit dalam rongga mulut.

Untuk penelitian selanjutnya, diharapkan dapat melakukan pemeriksaan laju aliran saliva dengan metode pengukuran stimulated saliva.

\section{DAFTAR PUSTAKA}

1. Kementerian Kesehatan. Profil Kesehatan Indonesia 2012. Jakarta: Kementerian Kesehatan RI, 2013; p. 68-9, 341.

2. Fajrin FN, Agus Z, Kasuma N. Hubungan body mass index dengan laju aliran saliva (studi pada mahasiswa Fakultas Kedokteran Gigi Universitas Andalas). Maj Ked Gi Ind. 2015; 1(2):156-62.

3. Indriana T. Perbedaan laju aliran saliva dan 
pH karena pengaruh stimulus kimiawi dan mekanis. J. Kedokt Meditek. 2011; 17(44):1-5.

4. Hedge MN, Kumari S, Hedge N, Moany A. Correlation between total antioxidant level and dental caries in adults - an in vivo study. RJPBCS. 2011;2(4):86470.

5. Mori F, Hiraishi N, Otsuki M, Tagami J. Effect of mastication on flow and properties of saliva. Asian Pac J Dent. 2012;12:1-5.

6. Pannuzio E, Amancio OMS, Vitalle MSDS, Souza DND, Mendes FM, Nicolau J. Analysis of the stimulated whole saliva in overweight and obese school children. Rev Assoc Med Bras. 2010; 56(1):32-6.

7. Alves C, Brandao M, Andion J, Menezes R. Use of graduated syringes for measuring salivary flow rate: a pilot study. Braz Dent J 2010;21(5):401-4.

8. Hopcraft MS, Tan C. Xerostomia: an update for clinicians. Aust Dent J. 2010; 55:238-44.

9. Yulyius, Bolang ASL, Kawengian SE. Hubungan antara status gizi dengan tekanan darah Program Studi Pendidikan Dokter angkatan 2013 Fakultas Kedokteran Universitas Sam Ratulangi. Ejournal Unsrat. 2014; 2(1):1-7.

10. Modeer T, Blomberg CC, Wondimu B, Julihn A, Marcus C. Association between obesity, flow rate of whole saliva, and dental caries adolescents. Obesity. 2010;18(12):2367-73.

11. Sawair FA, Ryalat S, Shayyab, Saku T. The unstimulated flow rate in a Jordanian healthy adult population. J Clin Med Res. 2009;1(4):219-25.

12. Hooley M, Skouteris H, Boganin C, Satur J, Kilpatrick N. Body mass index and dental caries in children and adolescents: a systematic review of literature published 2004 to 2011. BioMed Central. 2012;1(57):1-26.

13. Munevveroglu AP, Akgol BB, Erol T, Uysal B. Relationship between socioeconomic status, body mass index and dental caries of children. Adv Dent Oral Health. 2017;4(5):1-4.

14. Guare RO, Ciamponi AL, Maria MTBR, Gorjao R, Diniz MB. Caries experience and salivary parameters among overweight children and adolescent. Dent J. 2013;1:31-40.

15. Choromanska K, Choromanska B, Dabrowska E, Baczek W, Mysliwiec P, Dadan J, et al. Saliva of obese patiens - is it different?. Postepy Hig Med Dosw. 2015;59: 1190-5.

16. Yas BA. The relation of salivary antioxidants to dental caries among overweight and obese adult aged $30-40$ year old at textile factory in Mosul City. J Bagh Coll Dentistry. 2011; 23(sp. Issue):1415 . 